\title{
Could Acceptance Predict Commitment in Organisational Change? Impact of Changes Caused by Succession From the Viewpoint of Non-family Employees in Small Family Firms
}

\author{
Sari Savolainen \\ University of Jyväskylä, Jyväskylä, Finland
}

\begin{abstract}
Family business predecessor announced to staff that with his son, he is going to commence a succession process in the family firm. Two of the key employees rose and announced their intention to leave the company after the predecessor passed leadership of the firm to successor. In a firm with a total number of nine employees, such a situation can prove catastrophic. Why did these employees react that way? What is behind their motivation? Using these two employees as examples, this study discusses the elements which influence the development and continuance of employees’ organisational commitment. Inspired by the example, this study gives answers by means of qualitative research methods to the following research questions: Could acceptance predict the development and continuation of organisational commitment during a process of organisational change and how do the concepts of psychological acceptance adaptation and organisational commitment link together in employee cognitive processing during organisational change? The empirical setting of this study includes seven small family firms and the study has carried out an overview of family business succession (FBS) from the viewpoint of non-family employees in Finnish and Irish family firms. Results of the study indicate how employees' commitment forms and changes during a certain change process. A key element for development and the continuance of commitment is acceptance. As an outcome of this paper, a new model will be developed where acceptance, adaptation, and commitment (AAC-model) are combined, in essence, three dimensions (functional, legal-economic, and psychological) of changes in FBS.
\end{abstract}

Keywords: acceptance, adaptation, commitment, cognition, employee, succession, trust

\section{Introduction}

It is a long known fact that in family business succession (FBS) change in leadership is often the most challenging moment (Davis \& Harveston, 1998). In FBS discussion, the commitment of the successor and other family members has been shown by scholars to be crucial when it comes to measuring a successful succession-transition (Chrisman, Chua, \& Sharma, 1998; Handler, 1994; Sharma \& Irving, 2005; Sharma \& Rao, 2000; Sharma, Chrisman, \& Chua, 2003; Miller \& Le Breton-Miller, 2006; Dawson, Sharma, Irving, Marcus, \& Chirico, 2015). FBS inevitably brings different kinds of changes to organisational systems, daily

Sari Savolainen, Dr. of science economics and philosophy, Faculty of Information Technology, University of Jyväskylä, Jyväskylä, Finland.

Correspondence concerning this article should be addressed to Sari Savolainen, University of Jyväskylä, P.O. Box 35, 40014 JYU, Finland. 
routines, as well as improvements to different kinds of informal and formal agreements. This study concentrates on small family firms, such as those where there are only two organisation levels: leader/owners and non-family employees at the ground level. FBS research has so far neglected studies from the viewpoint of "ground level non-family employees", though it is increasingly viewed as an important topic in recent years (Sonfield \& Lussier, 2009). There is also a growing recognition of the role that employees play in the successful implementation of organisational change (Shin, Taylor, \& Seo, 2012). FBS scholars have highlighted the importance of commitment from the viewpoint of successor(s), predecessor(s), or family members (e.g., Handler, 1994; Sharma \& Irving, 2005; De Massis, Chua, \& Chrisman, 2008), but none of the earlier papers or studies has answered the following questions: Where does commitment come from? How it will develop (Bergman, 2006; Beck \& Wilson, 2001)? Finally, which matters affect its continuance? So far, scholars have been mostly interested in the issue of commitment from the viewpoint of its origins while research about development or the continuance of organisational commitment has been scant (Bergman, Benzer, Kabins, Bhupatkar, \& Panina, 2013).

So, why is the continued commitment of employees important? A practical answer can be given from the following example. In 2010, the author interviewed a predecessor, successor, and one employee representative for a case study. In that case, the predecessor and successor had decided to commence succession in 2004. At the time of the interview, succession had been going on over six years. The predecessor started the process by holding meetings with the staff (there were seven non-family employees) where he gave details of the succession plan. During one of the meetings two key staff members announced their decision to leave the firm on the same day the predecessor was finishing. In this case, the two employees were extremely important for the survival of the entire firm as they knew vital technical information and were able to take care of the most difficult work tasks. This example is useful, when it comes to describing the importance of development and the continuance of organisational commitment when organisational change occurs.

Inspired by the example and based on literature review, this study gives answers by means of qualitative research methods to the following research questions: Could acceptance predict the development and continuation of organisational commitment during a process of organisational change and how do the concepts of psychological acceptance adaptation and organisational commitment link together in employee cognitive processing during organisational change? Furthermore, this study looks at the types of changes that FBS brings about in a family firm and how they are connected to each other from the viewpoint of non-family employees.

\section{Theoretical Background}

\section{Organisational Commitment and Non-family Employees in FBS}

Meyer and Allen (1991) have argued that commitment can be seen as a psychological link that connects an employee to an organisation but the nature of the tie can differ individually. The first extensive theory of organisational commitment was provided by Mowday, Porter, and Steers (1982). According to them, organisational commitment is

The strength of an individual's identification with and involvement in a particular organisation, (which is) characterised by three factors: a strong belief in and acceptance of the organisation's goals and values; a readiness to exert effort on behalf of the organisation; and a strong desire to remain a member of the organisation. (Mowday et al., 1982, p. 27) 
Mowday et al. (1982) stated that commitment brings with its acceptance of organisational values and goals while Kübler-Ross (1969) and Elrod and Tippett (2002) argued that commitment demands the forming of acceptance. More often than not, organisational commitment is as an employee commitment connected to the entire organisation or firm, however, positive association or commitment can be directed at other areas such as subunits, an effective supervisor, or even particular program or event (Ford, Weissbein, \& Plamondon, 2003; Herscovitch \& Meyer, 2002). In the context of micro and small family firms, the target of employee commitment can be associated with the entrepreneur in the firm, this is because family firm entrepreneurs can have very strong characters (Kets de Vries, 1996; Miller, Steier, \& Le Breton-Miller, 2003), be very protective, and offer employees/members a type of paternalistic support and safety (Johannisson \& Huse, 2000; Koiranen, 2003).

Furthermore, family firm entrepreneurs are effective at creating trustful relationship with their employees. Trust implies mutual confidence where participants are not allowed to exploit the vulnerabilities of others or try to gain advantage over another (Nahapiet \& Ghoshal, 1998); this is especially true in family firms given their reliance on mutual trust (Corbetta \& Salvato, 2004). On one hand, high mutual trust can create positive affectivity and security of job continuity, which on the other hand can have causal effects to commitment in an organisational change situation (Iverson, 1996). In situations of FBS, it is important to remember that though predecessor and successor are members of same family, they do not always think alike. They represent different generations, see the world in different ways, and have different life values and experiences (Kets de Vries, 1996; Miller \& LeBreton-Miller, 2006). Though in FBS, there can be transference of different values between predecessor and successor, from generation to generation. Predecessor and successor are close family members, often parent, and child, that does not mean their personalities are similar or exactly the same, in fact, they often differ in terms of values, goals, and outlook. Family firms are often characterised by organisational commitment, present higher levels of loyalty, independence, and reciprocal altruism, which are socially embedded resources to supporting long-term organisational goals and the firm's success (Eddleston, Kellermanns, \& Sarathy, 2008).

In FBS, the predecessor represents continuity and can symbolise a safeguard for employees (Kets de Vries, 1996; Koiranen, 2003). Employees get to know the predecessor over the years of working together, they are familiar with procedures and processes while their assumptions about the future are often based on their past experiences (Beck, 1985; Snow, Corno, \& Jackson, 1994). A change of leadership, from predecessor to successor, can often mean the introduction of new ways of doing things; it can result in the need to adapt to new methods, procedures, and values. Leadership changes along with other organisational changes can increase feelings of uncertainty from the viewpoint of non-family employee (Mabey, Salaman, \& Storey, 2000; Driscoll, 1978; Guest, 1987). According to Fedor, Caldwell, and Herold (2006), adaptation demands can be the critical factor determining individual change reactions. A positive change may not always be good for certain employees, especially if they need to do most of the adjusting. Furthermore, Fedor et al. (2006) presented that to understand how changes impact individuals and the outcomes of change should be considered.

It seems that scholars have not found a common understanding for the start and development of organisational commitment (Beck \& Wilson, 2001). Studies of the causes of workplace commitments have so far focused on either antecedents of commitment or bases of commitment, rather than the development of commitment (Bergman et al., 2013). Organisational commitment is not eternal nor an unchanging employee phenomenon (Beck \& Wilson, 2001) and from that perspective, it is important to understand the mind 
mechanisms that affect the process of change. Events like organisational change have directly impacted employee commitment (Bergman et al., 2013) and FBS should be viewed more as an organisational change (Ip \& Jacobs, 2006).

\section{Change and Its Influence on Employees}

Changes in an organisation are often perceived by individuals as threatening, which is why all changes require careful planning and implementation so as to avoid mistrust combined with feelings of vulnerability and loss of security and wellbeing (Mabey et al., 2000; Driscoll, 1978; Guest, 1987). In FBS, changes in management and leadership force each individual to connect to the family business in order to build new relationships (Costigan, Ilter, \& Berman, 1998; Sundaramurthy, 2008). According to Waks (2007), organisational change means the rearrangement of the existing organisational structure to a new institutional form, which in practical terms means putting it in a new working order. It is possible to take from the literature several models, when it comes to implementing organisational change (Kotter, 1996; Greiner, 1998; Latta, 2009; Parry, Kirsch, Carey \& Shaw, 2014). Common to these models is the importance of concentrating leadership actions/leader's role around implementation and supporting change (Kotter, 1996; Greiner, 1998; Whelan-Berry, Gordon, \& Hinings, 2003; Parry et al., 2014).

Kübler-Ross (1969) found in her "change curve" model that human mind processes change along similar patterns. This Kübler-Ross model (1969) has since been adapted to other models of organisational change, such as Elrod and Tippett; (2002), Zell (2003), Freeman (1999), and Stuart (1995). Common to this model is that at the beginning of change, the human mind denies the change (e.g., Mirvis, 1985; Rashford \& Coghlan, 1989; Perlman \& Takacs, 1990; Reynolds, 1994). Mirvis (1985) maintained that employee reactions to change pass through four different stages, which include (1) disbelief and denial; (2) anger, rage, and resentment; (3) emotional bargaining beginning with anger and ending with depression; and finally (4) acceptance. His model is similar to Kübler-Ross' change curve (Figure 1). Kübler-Ross (1969) created her model by documenting the phases through which individuals pass when coping with trauma or serious/mortal illness. She identified five phases: (1) denial; (2) anger; (3) bargaining; (4) depression; and (5) acceptance.

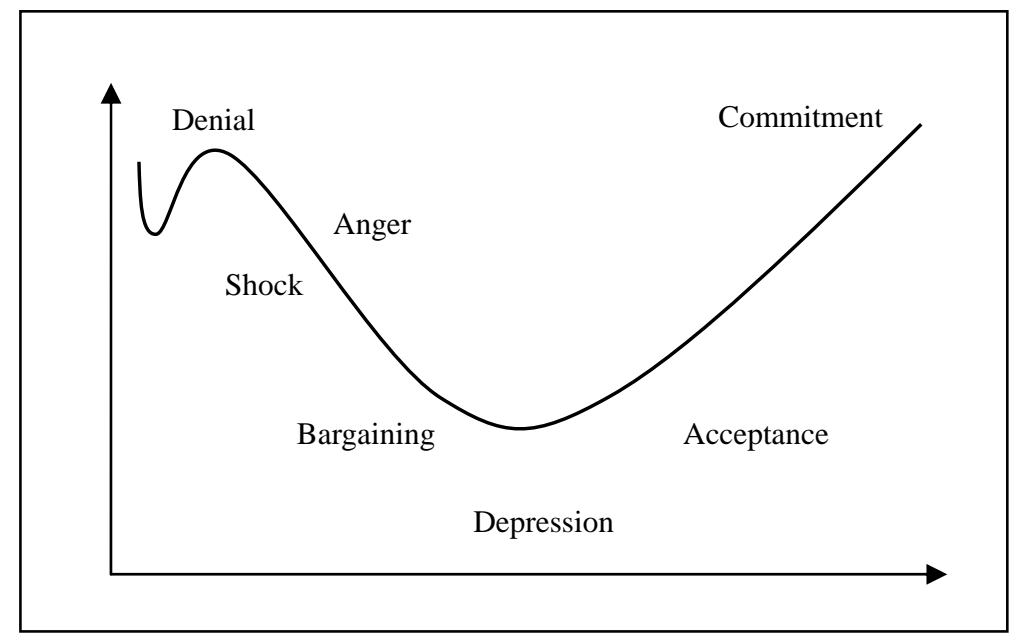

Figure 1. Change curve. Source: Kübler-Ross (1969).

In the context of FBS, it has been noted that organisational change can be extremely difficult for the successor to implement after the succession (Ward, 1997). Though FBS scholars have rigorously presented 
several models for implementing FBS and discussed the possibility of organisational changes that come with the process, they have not been interested in testing or studying the feasibility of some existing organisation change models that relate to the implementation of FBS. FBS differs from a change of in non-family firms, where the family business owners favour more personal, relationship-centred approaches to successor development, compared to non-family firm owners who prefer formalised, task-oriented development approaches (Welsch, 1993). This difference can influence a successor's development of organisational commitment (Savolainen \& Kansikas, 2013). Over the years, different scholars have presented that FBS encompasses leadership planning, change management, human resources, and many other areas of business involving change (Guest, 1987; Handler, 1994; Santiago, 2000). Ip and Jacobs (2006) have presented a model for business succession planning where they indicated that FBS brings along certain issues for leaders and owners that need to be taken into account.

\section{Connecting Psychological Phenomena}

Based on Kübler-Ross (1969), Mirvis (1985), and Ip and Jacobs (2006), it is possible to limit the number of psychological phenomena during organisational change to three key phenomena: acceptance, adaptation, and commitment. This is due to denial, shock, anger, bargaining, and depression, which in Kübler-Ross' model (1969) are purely human emotions that a person is forced to handle (see Figure 2) (Hayek, 1952; Beck, 1985; Snow et al., 1994). The most subconscious of these three minded phenomena is acceptance, because in acceptance it is a person's earlier cognitive experience-based information and emotions, which has resulted from experience (Hayek, 1952; Frijda, 1986; Lazarus \& Folkman, 1984). When a person handles information about organisational change, $\mathrm{s} / \mathrm{he}$ is not necessarily conscious about the details that lead to acceptance or rejection of those changes.

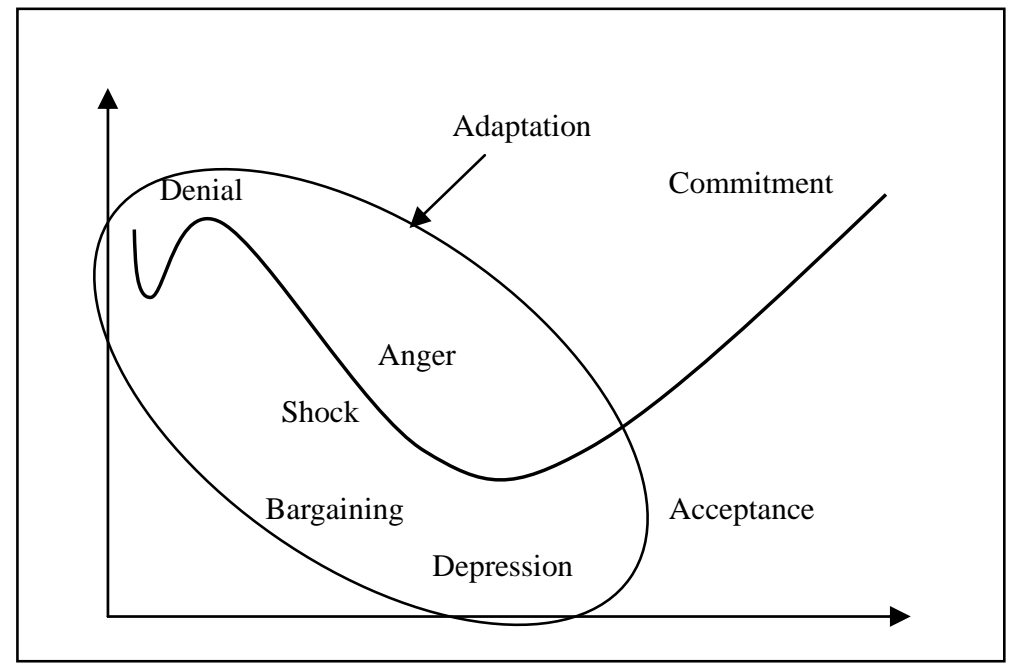

Figure 2. Adaptation in change curve. Source: Kübler-Ross (1969).

Acceptance. According to Hayes, Strosahl, and Wilson (1999), psychological acceptance (also called acceptance) points to the willingness to experience thoughts, feelings, and psychological emotions, especially those which are negatively evaluated (e.g. fear and uncertainty) without having to avoid them, or let them determine one's actions. Acceptance of these internal events allows people to use their energies more effectively, before giving in to resignation, avoidance, or control of these events and to act in a way that is 
congruent with their values and goals (Pieper, Klein, \& Jaskiewicz, 2008; Deci, Connell, \& Ryan, 1989). Acceptance encompasses the transfer of observational resources from controlling internal events to observing one's environment (Hayes et al., 1999). Acceptance as a psychological phenomenon is similar with trust (Rotter, 1967; Hayes et al., 1999), so that both of them are connected to a person's expectations about the future. Where trust is connected to the expectation that another person's or group's promise, oral, or written statements can be trusted (Rotter, 1967). Acceptance refers to the willingness to experience events in the future. Furthermore, both rest on a person's capabilities to process psychological changes and face events (Kavanagh \& Ashkanasy, 2006).

Organisational change literature outlines how to support employees' acceptance and adaptation to change (Gagne, Koestner, \& Zuckerman, 2000; Kavanagh \& Ashkanasy, 2006). For instance, the literature mentions that participation, communication, and empathy can facilitate employee acceptance of change (Gagne et al., 2000). The literature shows that rational work tasks, offering some choice how to do the task, and acknowledging feelings about the task, all support employees' acceptance while organisational change is occurring.

Adaptation. A broad definition of the term adaptation is the gradual decrease of the organism's response to repeated exposure to a stimulus, involving all the actions that make it better suited to survive in such an environment (Nikopolou \& Steemers, 2003). Correspondingly Piaget (1926; 1930) linked adaptation to cognitive psychology in that adaptation to the physical and social environment and its laws occurs when each individual develops the essential types of thought, which makes it possible to survive in the world. Adaptation is an active psychological processing of the environment where the individual uses the previously-formed mental structures, schemes, editing, and interpretation of the environment (Piaget, 1926; Beck, 1985; Snow et al., 1994). In adaptation, every fresh external influence exercised upon the mind of a person presupposes two opposite processes. First, the person adapts to the object which exercises this influence and a schema is formed that relates to the new object (Beck, 1985; Snow et al., 1994). Second, this adaptation implies that between the new and the old habits, there is certain continuity. Silverthorne (2005) has stated that adaptation with flexibility is the key to organisational survival in a conflict situation, while conflicts in organisations can lead to change and correspondingly change leads to adaptation.

Adaptation as a process of the mind follows a definite pattern and is based on a person's perception about the environment or organisation (Piaget, 1926; Beck, 1985; Snow et al., 1994). Adaptation to change in an organisation starts with a person's information scanning, where the person collects relevant observations about changes and events in the organisation's environment (Milliken, Dutton, \& Beyer, 1990). It has some similarities with adaptation and cognitive information processing (Beck, 1985; Snow et al., 1994). The first similarity is noticing how important information is based on the scanning of observations, so that certain observations receive attention and in the person's mind a process starts to interpret the meanings of the observation (Piaget, 1926; Beck, 1985; Snow et al., 1994). Secondly, the interpreting of observations which are combined with earlier interpretations leads to individual or organisational learning (Håkonsson, Obel, \& Burton, 2008; Damasio, Everitt, \& Bishop, 1996; Jimmieson, Terry, \& Callan, 2004).

Commitment. Organisational commitment is defined as the strength of an individual's identification with and involvement in a particular organisation (Porter, Steers, \& Mowday, 1974). This kind of commitment can be characterised with factors, such as an individual having a strong belief in acceptance of the organisation's goals and values, has a willingness to exert considerable effort on behalf of the organisation, and has a definite 
desire to maintain ties within the organisational membership (Pieper et al., 2008; Eddleston, Chrisman, Steier, \& Chua, 2010; Davis, Allen, \& Hayes, 2010). According to Iverson (1996), organisational commitment can be considered to take on a mediating role in organisational change. Organisational commitment increases employees' adaptation to changes and creates an open atmosphere of change among employees (Stace \& Dunphy, 1991; Guest, 1987). Furthermore, employees who experienced a high level of job security will likewise experience a high level of organisational commitment (Iverson, 1996).

Scholars generally agreed that commitment can be described by two separate but related concepts, i.e., attitudinal and behavioural commitment (Iverson, 1996). According to Guest (1987), attitudinal commitment is referred to as affective organisational commitment and represents the degree of loyalty an individual has for an organisation, specifically, an individual's identification and involvement in the organisation. Behavioural commitment covers those processes which individuals use to link themselves to an organisation and focuses on the actions of the individuals (Scott, 1987; Iverson, 1996). In the context of FBS, Sharma and Irving (2005) have handled commitment from the successor viewpoint. Sharma and Irving (2005) have presented four different dimensions of commitment: affective as desire based, normative as obligation based, calculative as opportunity based, and imperative as needs based.

According to Iverson (1996), the attitudinal component of organisation commitment can be more applicable to human resource policy formation. Correspondingly, Guest (1987) mentioned that attitudinal based organisational commitment combined with work-related behavioural commitment will result in high employee satisfaction, high performance, longer tenure, and willingness to accept change. Meyer and Allen (1991) presented that commitment as having three different components (affective, normative, and continuance) which develop in different ways and have different implications for work behaviour.

\section{Methodology}

\section{Research Framework}

This case study adopts a multiple case study approach (Yin, 1994). The reason for choosing the multiple case study approach was its ability to capture relations among various items, to study them in context and also to deepen the analysis in as much as first-round analyses tend to offer only limited results (Siggelkow, 2007; Easton, 2009). Multiple-case studies allowed for a comparison between cases and various cases were utilised to identify similarities and differences as well as to replicate findings among them (Eisenhardt \& Graebner, 2007). This study has carried out an overview of FBS from the viewpoint of non-family employees in Finnish and Irish family firms. The study has examined how non-family employees handle changes brought about by FBS and the influences FBS has on non-family employees' organisational and change commitment. Four limitations were defining while selecting cases for this study. First limitation was size of the case; all selected cases had only two organisation levels: leader/owners and ground level employees. Second limitation was timing of succession; FBS must have been going on at least few years or finished only two years before this study. The third limitation was that cases were not allowed to cooperate or conduct any business together. The final fourth limitation was that all cases had to provide a willing successor and one non-family employee representative. These limitations made implementation of the study difficult because family firms implementing FBS were not open to tell their stories. Especially difficult was finding family firms where non-family employees were voluntary or allowed to participate in the study. 


\section{Empirical Setting and Research Design}

The empirical setting of this study includes seven small family firms. While selecting seven cases for this study, the above mentioned limitations minimized external variation beyond the phenomenon of interest (Eisenhardt, 1989). Now selected cases are homogenous under four dimensions. As cases are selected from two different countries, there are some cultural and economic differences, which might have a small influence on FBS implementation (Table 1 presents a small synopsis of the differences between these two countries). The economic situation is also reflected in people's minds, how they see their future, etc. In Ireland, the economy has started to improve after a huge banking collapse, followed by deep recession. In Finland, the economy is in decline and quite a number of employees worry about job security. Culturally, Irish people are more optimistic and relaxed. On one hand, they make promises which are not a serious obligation to fulfil; the Finns on the other hand keep the promises they make.

Table 1

Analysis of National Differences Between Ireland and Finland

\begin{tabular}{lll}
\hline & Ireland & Finland \\
\hline General economic situation & Improving after huge collapse & Still going down or in recession \\
Taxation in FBS & No inheritance tax necessarily & Predecessor or successor taxed \\
Employee unions & Employees are not so involved in Unions & Very strong influence \\
Price level & $-9 \%$ & 0 \\
Average salary & $€ 38,000$ & $€ 37,332$ \\
People attitude towards future & Waiting or improving & Waiting or weakening \\
People attitude towards given promises & Promises can be made, but then not taken & Given promise has to be fulfilled \\
People attitude towards life & so seriously & More serious \\
People attitude towards rules and orders & Flexible & Rules have to be followed \\
People attitude towards money & Use if you have it & Save \\
\hline
\end{tabular}

In Finland, such a situation leads to the successor being taxed, according to an approximate valuation of the company. The Finnish labour market is quite inflexible because of strong employee union, which makes employers a bit more reluctant, when it comes to hiring more employees. This means that employees try to hold onto the positions they have, which can further influence change resistance and make it more difficult to accept changes that occur in organisations.

Along with cultural and national differences, the seven family firms are active in six different industries (bakery, building supplies, fast-food, food shop, HVAC sales \& repairs, and metal industry) —a deeper cross-case analysis is given in Table 2. All the cases can be characterised by different features in terms of family structure and relationships, previous work experience of the successor both within and outside of the family firm, difference in implementation of succession, and use of advice while planning and implementation of succession. Though two cases are in the same field of business, they are otherwise very different. In some cases, FBS implementation has been stormier than in others.

\section{Data Analysis}

This study aims to analyse how different types of changes caused by FBS connect to one another. It also aims to explore the reasons for differences, especially as these differences are related to the degree of complexity and the processes leading to (or are related to) such complexity. To empirically explore these topics, an interpretative approach of grounded theory that was based on case-study data was employed. According to 
Nordqvist, Hall, and Melin (2009), the interpretative approach is useful when analysing the insights from family businesses due to the complex realities associated with family businesses. Following typical inductive and imperative multicase research form (Miles \& Huberman, 1994; Eisenhardt, 1989; Yin, 1994), the data were analysed by first building individual case study summaries, synthesizing, and comparing interview transcripts. Throughout that process scholars had to be critical in interpretations and not allow own thoughts or presumptions to influence the findings, which was to ensure the internal and external validity of the case summaries and emerging findings.

Table 2

Cross-case Analysis

\begin{tabular}{|c|c|c|c|c|c|c|c|}
\hline & Case 1 & Case 2 & Case 3 & Case 4 & Case 5 & Case 6 & Case 7 \\
\hline Field of business & Bakery & Food shop & Building sup. & Fast food & HVAC sales & Metal ind. & Bakery \\
\hline Location & Ireland & Ireland & Ireland & Ireland & Finland & Finland & Finland \\
\hline Non-family employees & 35 & 18 & 16 & 6 & 6 & 4 & 10 \\
\hline Generation in charge & Third & Third & Second & Third & Second & Second & Second \\
\hline Stage of FBS & Going $3 \mathrm{y}$. & Going $6 \mathrm{y}$. & Going $3 \mathrm{y}$. & 2 y. ago & Going $5 \mathrm{y}$. & Going $5 \mathrm{y}$. & Going $5 \mathrm{y}$. \\
\hline Next-gen. member as leader & Yes & Yes & Yes & Yes & Yes & Yes & Yes \\
\hline Predecessor still in business & Yes/fulltime & Yes/ halftime & $\begin{array}{l}\text { Yes /fulltime } \\
\text { No/retired }\end{array}$ & No & Yes/ halftime & Yes/fulltime & Yes/fulltime \\
\hline Role of predecessor & Employee & Advisor & Manager & - & Advisor & Manager & Empl./leader \\
\hline Pred./successor conflicts & Rarely & Sometime & Weekly & - & Weekly & Rarely & Almost daily \\
\hline Gender pred./successor & Fem./fem. & Fem./male & Male/male & Male/fem. & Male/male & Male/male & Male/male \\
\hline Successor/NFE conflicts & Rarely & Rarely & Rarely & Sometime & Weekly & Rarely & Daily \\
\hline
\end{tabular}

This study has been purely based on empirical findings and followed a qualitative content analysis. It sought similarities from interviewees' stories which expressed their information handling and psychological processing when it came to changes in the family businesses. Analysis of data followed a process described in Figure 3. Though the study includes data from two different countries and cultures, it was possible to find similarities from interviewees' psychological processes. The depth of processes varied among cases even within the same country and by the challenges and changes FBS brought.

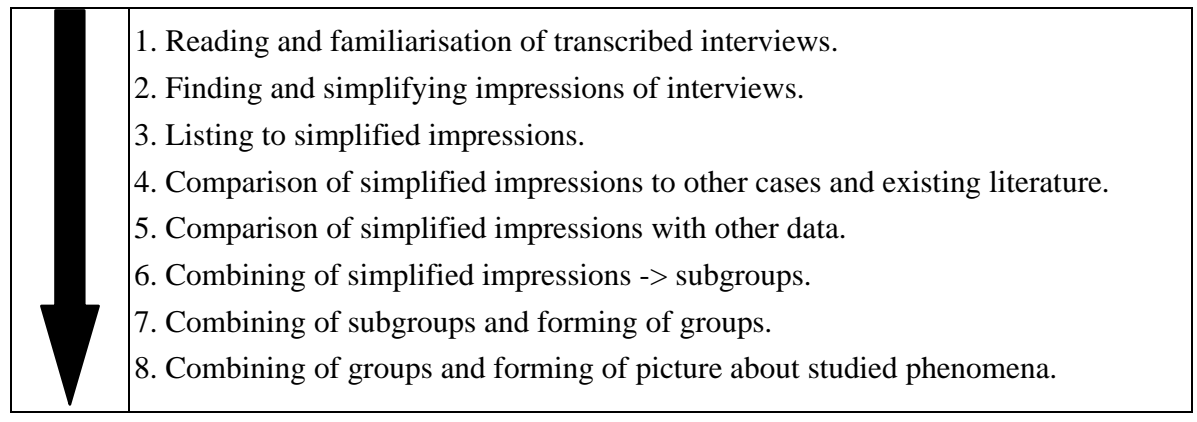

Figure 3. Process of data analysis.

\section{Results}

Based on the results, FBS can be divided into three dimensions: legal-economic, functional, and psychological changes (see Table 3). Functional changes are real actions associated with the daily operations in family firms. There is also the implementation of working orders for daily tasks, as well as the implementation 
of strategic decisions by the owners of the family firm. Legal-economic changes are connected to economic and legal issues like funding of daily actions or investments, and legal issues like agreements with employees or subcontractors (see Figure 4). Psychological changes follow functional and legal-economic changes; the psychological dimension of changes can include all changes that happen to the mind. How an individual reacts to information about a change is a very personal issue, which is influenced by a person's values, life expectations and experiences, social ties and connections, etc. Information about change raises feelings and launches a need to process the effects of change. Small and positive change can be easier to accept and adapt than larger and negative change, especially if change and its implementation will produce positive emotions and shift of organisational commitment (Shin et al., 2012).

Table 3

Distribution of Change Dimensions in FBS

\begin{tabular}{|c|c|c|}
\hline Functional dimension & Legal-economic dimension & Psychological dimension \\
\hline * Daily management actions & * Issues of ownership & * Reforming of commitment \\
\hline * Daily leadership actions & * Family membership & * Trust and its development \\
\hline $\begin{array}{l}\text { * Implementation of business strategies } \\
\text { * Daily family actions }\end{array}$ & $\begin{array}{l}* \text { Organisational membership } \\
* \text { Defining business strategies }\end{array}$ & $\begin{array}{l}\text { * Cognitive information handling } \\
\text { * Emotions, feelings, affections } \\
\end{array}$ \\
\hline * Negotiations etc. & * Members of board \& council & * Psychological ownership and \\
\hline * Negotiations etc. & * Contracts \& engagements & belonging to organisation \\
\hline * Implementation of board decisions & $\begin{array}{l}\text { * Financial investments } \\
\text { * Board and council actions } \\
\text { * Agreements and instructions }\end{array}$ & $\begin{array}{l}\text { * Tensions, conflicts, ideologies } \\
\text { * Respects, values, social cultures } \\
\text { * Adaptation, acceptation, etc. }\end{array}$ \\
\hline
\end{tabular}

Planned FBS can give employees time to accept and adapt to change, especially if s/he is allowed to join or follow the decision making process associated with the succession implementation. In the case where succession happens because of the passing of a predecessor, grief adds to the psychological stress of employees. Furthermore, it seems to be the case that all three dimensions are connected to each other. Both functional and legal-economic changes bring along psychological changes, e.g., need to accept or to adapt to change. Legal-economic changes mostly require acceptance and functional changes around adaptation. Correspondingly, legal-economic changes often bring along changes to organisational functions.

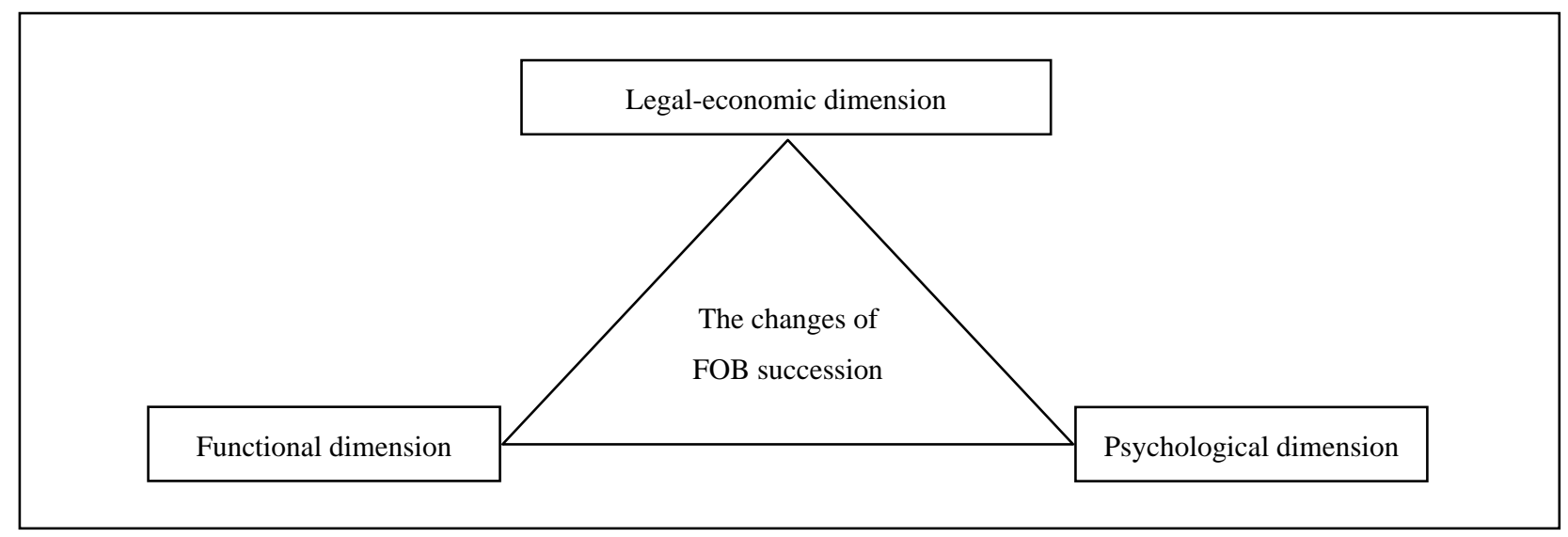

Figure 4. Three FBS dimensions of changes.

With differences between cases, nationality, field of business, or success in FBS implementation, it is easy to find similarities in employees' psychological processes (see Table 3). In all cases, employees' acceptance 
followed the same pattern whether the employee felt the situation in family firm improved or worsened as a result of FBS, or which country or case the employee was located.

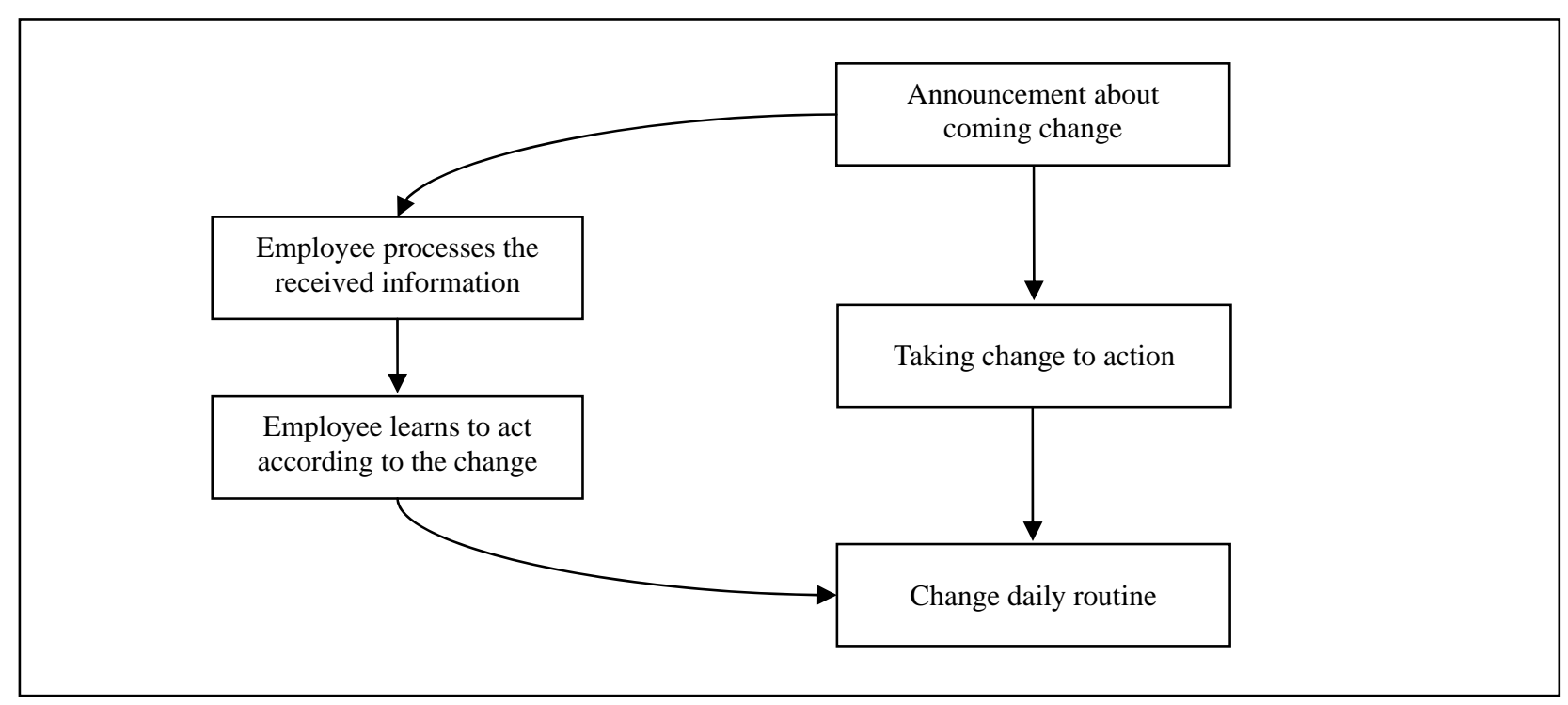

Figure 5. Employee change processing. Source: Ip and Jacobs (2006).

This was especially true in cases 4, 5, and 7 where employees stated that their acceptance towards the successor, changes in agreements, and successor's decision making had varied during the succession implementation (Table 4). In cases where the successor was respectful and brought positive changes to the family firm, acceptance and adaptation to changes caused by FBS had developed more positively. Furthermore, employees' acceptance to the start of succession varied a lot, e.g., in case 5, employees could not accept the start of succession or successor. While in case 6, employees had encouraged the successors to run the family firm after the predecessor. Results indicate that if the predecessor is not able to give space for the successor to take the lead in the firm then friction can arise between predecessor and successor, which impacts directly on the employees' acceptance of the entire process.

In all cases, acceptance was connected to expectations about the future, willingness to fulfil agreements, accept decisions and instructions, or orders. If an employee was not able to accept the successor as his/her leader, this reflected the employee's capability to accept successor's instructions and orders. Furthermore, the lack of acceptance influenced the employee's willingness to renew or fulfil agreements. When the employee accepted the successor to be his/her leader, that eased further acceptance to changes of agreements and instructions and orders.

Adaptation, as a psychological process, can be defined as getting used to cooperating with the successor, taking action when it comes to changes of agreements, implementing instructions, and orders in the day-to-day business activities. Acceptance links to adaptation so that higher acceptance predicts easier adaptation and difficulties in acceptance and difficulties in acceptance indicate difficulties with adaptation.

Employees' commitment to changes and organisation varied in connection with their psychological process of acceptance and adaptation. In cases where employees' psychological process of acceptance and adaptation had been positive, commitment to changes and organisation had developed positively. If employees felt difficulties in acceptance and adaptation, it was reflected immediately in their commitment. 
Table 4

Main Results Case by Case

\begin{tabular}{|c|c|c|c|}
\hline & Acceptance & Adaptation & Commitment \\
\hline $\begin{array}{l}\text { Case } 1 \\
\text { Bakery }\end{array}$ & $\begin{array}{l}\text { Employee feels easy to accept } \\
\text { decision because predecessor and } \\
\text { successor make decisions together, } \\
\text { employee sees that their changes have } \\
\text { developed firm positively. }\end{array}$ & $\begin{array}{l}\text { Successor gives lots of responsibility } \\
\text { and independence to employee to do } \\
\text { their work which improves their } \\
\text { adaptation to functional changes. }\end{array}$ & $\begin{array}{l}\text { Commitment and vision about family } \\
\text { firm's future are improved, because } \\
\text { employee feels easy to accept } \\
\text { agreements and adapt functional } \\
\text { changes. }\end{array}$ \\
\hline $\begin{array}{l}\text { Case } 2 \\
\text { Food shop }\end{array}$ & $\begin{array}{l}\text { Employee has got lots of respect from } \\
\text { predecessor and successor has not } \\
\text { changed that situation. This has made } \\
\text { it easier for employee to accept } \\
\text { agreements, new orders, and the } \\
\text { change of the leader. }\end{array}$ & $\begin{array}{l}\text { Successor gives lots of responsibility } \\
\text { and independence to employee to do } \\
\text { their work which improves their } \\
\text { adaptation to functional changes. } \\
\text { Employee feels that he is like a } \\
\text { member of owning family. }\end{array}$ & $\begin{array}{l}\text { Commitment and vision about family } \\
\text { firm's future are improved, because } \\
\text { employee feels easy to accept } \\
\text { agreements and adapt functional } \\
\text { changes. }\end{array}$ \\
\hline $\begin{array}{l}\text { Case } 3 \\
\text { Build supp. }\end{array}$ & $\begin{array}{l}\text { Friction between successor and in } \\
\text { business still actively action other part } \\
\text { of predecessors causes difficulties to } \\
\text { acceptance. Employee sees successor } \\
\text { as a leader, accepts his decisions and } \\
\text { orders, and dismisses orders of } \\
\text { predecessor. }\end{array}$ & $\begin{array}{l}\text { Situation between successor and other } \\
\text { part of predecessors has caused } \\
\text { difficulties to adapt changes of } \\
\text { succession. Employee avoids } \\
\text { connection with predecessor and } \\
\text { certifies orders and instructions of } \\
\text { daily actions from successor. } \\
\end{array}$ & $\begin{array}{l}\text { Commitment still high, but waits what } \\
\text { happens in the future. }\end{array}$ \\
\hline $\begin{array}{l}\text { Case } 4 \\
\text { Fast-food }\end{array}$ & $\begin{array}{l}\text { Successor has brought along } \\
\text { sharpness and clearness to decision } \\
\text { making, instructions, and agreements. } \\
\text { Further successors trust to employee } \\
\text { has positive influence acceptance of } \\
\text { employee. }\end{array}$ & $\begin{array}{l}\text { Employee feels to be a member of } \\
\text { owning family, he trusts successor's } \\
\text { orders and instructions and knows } \\
\text { how to do daily works. He says that } \\
\text { changes have been easy to take in use } \\
\text { and to adapt them. }\end{array}$ & $\begin{array}{l}\text { Employee says that his commitment to } \\
\text { work and changes has improved, } \\
\text { because he feels to be member of } \\
\text { family and successor respects him. }\end{array}$ \\
\hline $\begin{array}{l}\text { Case } 5 \\
\text { HVAC }\end{array}$ & $\begin{array}{l}\text { For employee, it is difficult to accept } \\
\text { successor as a leader because of thigh } \\
\text { control and formal decision making. }\end{array}$ & $\begin{array}{l}\text { Formal and delayed decision making } \\
\text { makes it difficult to adapt situation in } \\
\text { the firm. }\end{array}$ & $\begin{array}{l}\text { Commitment decreased because of } \\
\text { difficulties of acceptance and } \\
\text { adaptation. }\end{array}$ \\
\hline $\begin{array}{l}\text { Case } 6 \\
\text { Metal }\end{array}$ & $\begin{array}{l}\text { Agreements are easy to accept, } \\
\text { because still predecessor holds the last } \\
\text { word. Employee has accepted to } \\
\text { follow family meeting decision } \\
\text { making, vision about future positive. }\end{array}$ & $\begin{array}{l}\text { Adaptation to changes and actions in } \\
\text { firm is easy, because employee has } \\
\text { joined decision making. So he had } \\
\text { time to consider influences of making } \\
\text { decisions to daily actions. }\end{array}$ & $\begin{array}{l}\text { Commitment was improved, because } \\
\text { all happens according to agreements } \\
\text { and employee feels easy to adapt } \\
\text { situation in family firm. }\end{array}$ \\
\hline $\begin{array}{l}\text { Case } 7 \\
\text { Bakery }\end{array}$ & $\begin{array}{l}\text { Between predecessor and successor, it } \\
\text { is difficult to hold on agreements. } \\
\text { Employee sees difficulties to accept } \\
\text { the successor as a leader, accepting of } \\
\text { orders, and instructions difficult. }\end{array}$ & $\begin{array}{l}\text { Both predecessor and successor try to } \\
\text { act as a leader, both their orders and } \\
\text { instructions are overlapping, which } \\
\text { makes it difficult for employees to } \\
\text { adapt situation. }\end{array}$ & $\begin{array}{l}\text { Broken agreements and confusions in } \\
\text { daily actions reflect employees } \\
\text { commitment which have reduced } \\
\text { because of difficulties to adapt } \\
\text { situation. }\end{array}$ \\
\hline
\end{tabular}

\section{Discussion}

This study has shown that commitment to membership of an organisation is not an unchangeable psychological phenomenon (Mowday et al., 1982). Results of the study indicate how employees' commitment forms and changes during a certain change process. A key element for development and the continuance of commitment is acceptance. When an employee accepts change, either partly or completely, s/he will start to adapt to the consequences of the change being implemented. Acceptance of internal events and changes caused by FBS make it possible for people to use their energies more effectively, before giving in to resignation, avoidance, or control of these events, to act in a way that is congruent with their values and goals (Pieper et al., 2008; Deci et al., 1989). Like scholars who have earlier presented, adaptation as a process of the mind follows a definite pattern and is based on a person's perception about their environment or organisation (Piaget, 1926; Beck, 1985; Snow et al., 1994). 
This study has shown that mind acceptance and adaptation processes are connected while forming organisational and change commitment (see Table 5 and Figure 5). According to the results, employees look to handle acceptance at the moment they receive information about change. This information appears to be connected to legal-economic changes, like owners' decisions, written, or oral agreements, leaders' instructions etc. The first step in an employee's psychological process of change occurs at the moment information is received; this is the moment when some acceptance to the proposed changes has to be found. The difference in all these cases compared to earlier literature is at the moment of acceptance. Mirvis (1985), Kübler-Ross (1969), Elrod and Tippett (2002) have argued that acceptance forms during the time an employee adapts to a change, whereas Mowday et al. (1982) stated that organisational commitment brings acceptance with it. Results of the study indicate that acceptance appears to be a key element, when it comes to adaptation and the furthering of organisational development and change commitment.

Table 5

\section{Common With All Cases}

\begin{tabular}{|l|l|l|l|}
\hline & Acceptance & Adaptation & Commitment \\
\hline $\begin{array}{l}\text { Leader } \\
\text { change }\end{array}$ & $\begin{array}{l}\text { In FBS, acceptance appears very } \\
\text { much related to change of leader, } \\
\text { from predecessor to successor. }\end{array}$ & $\begin{array}{l}\text { Adaptation to FBS is related much } \\
\text { more to adapting to the manners and } \\
\text { habits of the new leader. }\end{array}$ & $\begin{array}{l}\text { Commitment to new leader appears to } \\
\text { develop through acceptance and } \\
\text { adaptation process, how the employee } \\
\text { is able to accept successor as leader } \\
\text { and how the employee adapts to } \\
\text { changes the successor brings along. }\end{array}$ \\
\hline $\begin{array}{l}\text { Dimension of } \\
\text { change }\end{array}$ & $\begin{array}{l}\text { Further acceptance seems to be } \\
\text { connected to agreements and decision } \\
\text { making, how to accept agreement or } \\
\text { decisions of leader. }\end{array}$ & $\begin{array}{l}\text { Adaptation appears to be connected to } \\
\text { decision implementation and } \\
\text { adaptation of changes caused by FBS. }\end{array}$ & $\begin{array}{l}\text { Commitment comes from the base of } \\
\text { acceptance of legal-economic factors } \\
\text { and adaptation to functional changes. }\end{array}$ \\
\hline $\begin{array}{l}\text { Psychological } \\
\text { process }\end{array}$ & $\begin{array}{l}\text { Behind acceptance, emotions, norms, } \\
\text { values, etc. can be found, which } \\
\text { means that these psychological } \\
\text { phenomena have influenced } \\
\text { employees' acceptance process. }\end{array}$ & $\begin{array}{l}\text { Adaptation process seems to increase } \\
\text { emotions, which further reflects the } \\
\text { psychological process of adaptation. }\end{array}$ & $\begin{array}{l}\text { Commitment comes from the base of } \\
\text { psychological processes of } \\
\text { acceptance and adaptation. }\end{array}$ \\
\hline
\end{tabular}

\section{Conclusions}

This paper has taken a micro process perspective to events around FBS from the viewpoint of non-family employees. The aim of this study has been to examine the changes FBS brings about and how different types of changes are connected to each other. The study has examined FBS from the viewpoint of non-family employees as well as looking at how an employee's commitment continues and develops during FBS. Earlier theories supported empirical findings and based on such empirical findings and theory, it is possible to create a new model (Figure 6). The model combines dimensions of changes caused by FBS and psychological phenomena which support non-family employees' commitment forming and continuance.

This paper advances the understanding of the human psychological process while seeking a better understanding of changes occurring in family firms during the succession process. Empirical findings have made it possible to note that compared to earlier theories (Mowday et al., 1982; Kübler-Ross, 1969), acceptance is present in employee psychological processing much earlier than existing theories that have been previously presented. The model gives the first glimpse at phenomenon that influences commitment forming, where acceptance and adaptation processes appear to be sine qua non for commitment continuance and forming. Compared to earlier ideas, it is possible from what the author has presented above to conclude that the need to 
accept is already present at the moment a person receives information about oncoming organisational change. Certain motivators and types can be found behind employee acceptance which affects the development of the final level of acceptance. According to the results, it appears that employee psychological acceptance towards change could predict future development and continuance of organisational commitment-this result has limitations and needs further study.

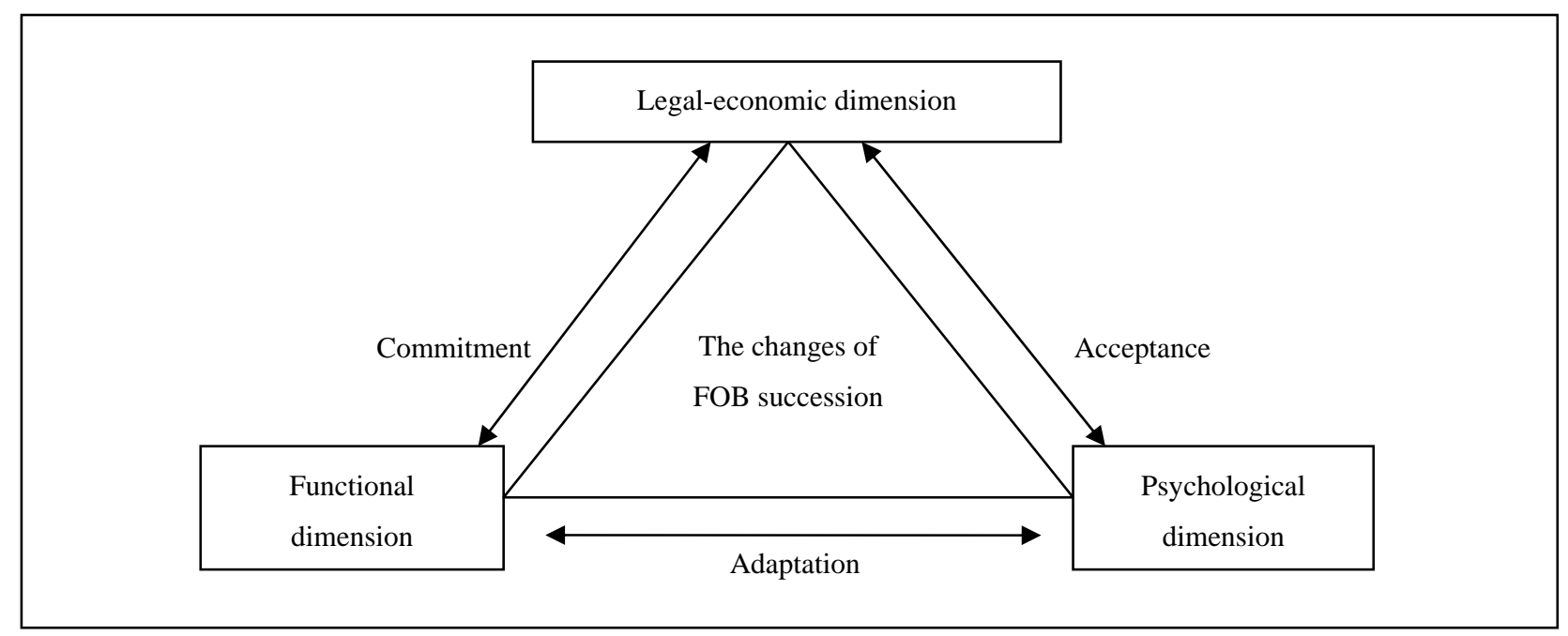

Figure 6. Acceptance, adaptation, and commitment (AAC) model.

Before a person receives information about change in an organisation, s/he has a pretty stable acceptance and commitment to the organisation and its activities. When an employee receives information about a change in the organisation, it will force him/her to evaluate his/her level of acceptance concerning that change. The information can also launch a re-evaluation process about membership in the organisation. Acceptance concerning the change can start from zero or it can start somewhere from between zero and full acceptance, especially if a person has some kind of positive pre-understanding about the meanings of the change (Beck, 1985; Snow et al., 1994).

If an employee cannot accept the change s/he is informed of, s/he can resign. In cases where an employee does not reject the change totally, s/he will continue working in the organisation and will adapt to the consequences of change from the start. Over time, acceptance and adaptation strengthen his/her commitment to the change and to the organisation to the level of commitment that existed before the change commenced (Figure 7). The need for psychological processing of the change will affect the development of the employees' acceptance. If change is small, it will be easier to accept, the need to adapt is smaller, and the affect on commitment is mild. Accordingly, big change causes a stronger need to adapt to a situation and develop acceptance (Figure 8). The period after the implementation of change brings experiences in relation to the impact of change. These experiences can affect the adaptation process as well as the development of acceptance level. If experiences are supportive for adaptation and acceptance, then the level of commitment will rise.

What happened in the case mentioned at the beginning of this article? Two years after the interview the successor told that in spite of all the efforts he and the predecessor made to support the employees' acceptance and adaptation to changes caused by FBS, the employees resigned, which occurred only two months before the predecessor was supposed to fully retire. Though successor and predecessor somehow were able to anticipate the resignation of these employees, it still left a huge knowledge and skill gap. In this case, the employees' 
experiences during implementation of succession did not support the development and continuance of employee commitment. This case also very clearly presents that level of acceptance or in this case unacceptability predicted development and continuance of employee organisational commitment.

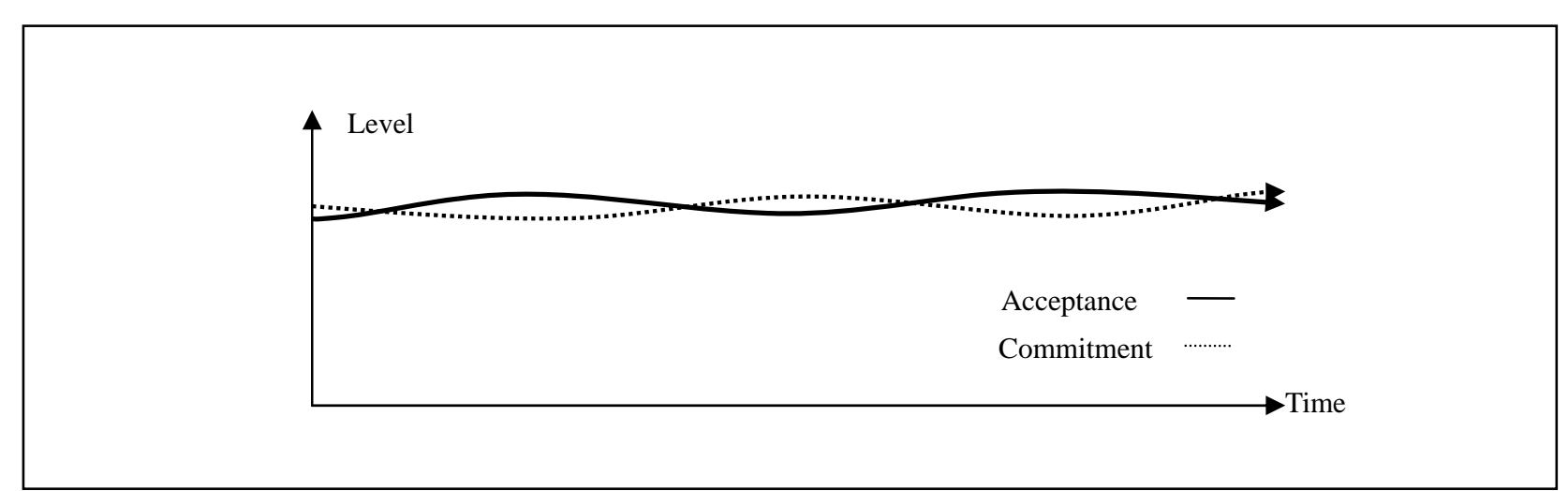

Figure 7. No change no change curve, level of commitment stable.

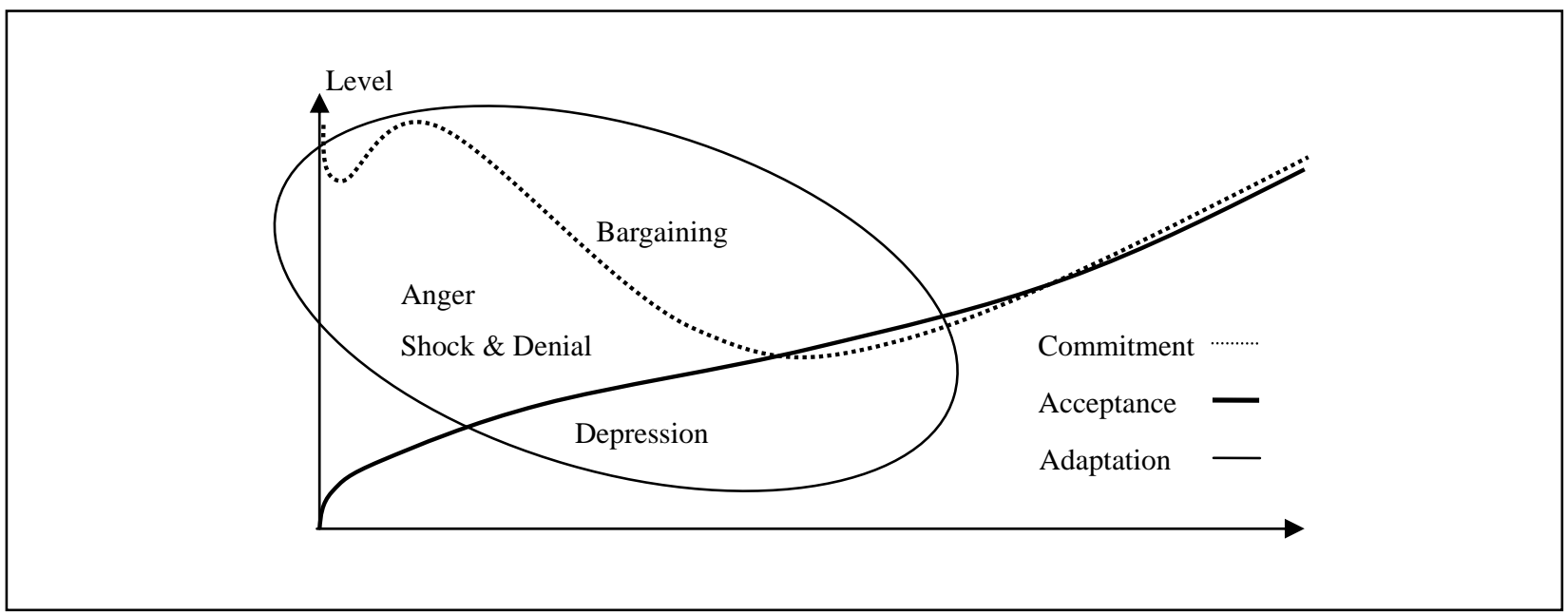

Figure 8. Big change—-steep change curve. Source: Kübler-Ross (1969).

This paper has some limitations the most important of which is case study method, the results describe the situations in the studied cases which do not allow for generalisations without further study. Firstly, the article is based on a limited number of cases and from a rather limited region, from two countries Europe: Finland and Ireland. Secondly, all family firms that were studied were small size firms. These limitations do not have to be determinated, because studied psychological phenomena can appear as well in larger organisations and in contexts other than family firms. This is first time however that a connection among acceptance, adaptation, and commitment has been expressed. It requires more studies especially in terms of a quantitative approach where the hypothesis is tested. This study has not tried to give any explanations as to why an employee's psychological process is influenced at the moment $s / h e$ is informed about a change. Furthermore, during adaptation, there can be events that may influence the development and continuance of commitment but which might not have any connection to an employee’s psychological acceptance.

Practical implications can be presented. Firstly, it appears to be of importance for family firm leaders and managers to support the forming of employee acceptance. According to the results, support can be giving time 
to accept change, involve employees in the decision making process, being respectful and maintaining trustful relationships with employees (Gagne et al., 2000). Secondly, the fact that family firms hold to traditions that have been built up, helps with the acceptance phenomenon from the viewpoint of employees (Wennberg, Wiklund, Hellerstedt, \& Nordqvist, 2011). Thirdly, according to Lines and Selart (2013), improvement of work environment and effective social interaction facilitates employee change acceptance. Finally, the length of time the predecessor stays in the family firm has a direct and significant impact on the ability of employees to adapt, commit, and cooperate with the successor. This result is identical with the results of non-family CEO succession studies (Friedman \& Saul, 1991; Friedman \& Singh, 1989).

The following recommendations can be made for future research in this area: Firstly, as mentioned above, this model needs to be studied more rigorously (quantitative method). Secondly, it could be that behind employee acceptance, similar forms (affective, normative, imperative, and calculative) could be detected, which have a connection to commitment (Sharma \& Irving, 2005). While ways to support employees' acceptance, adaptation, and continuance of commitment are mentioned in this paper, it would be good to study that particular aspect more rigorously. Moreover, results from this study point towards how and when an employee accepts information and opens of the possibility of predicting an employee's commitment to his/her organisation, which also requires more detailed study and analysis. Finally, employee reactions to negative succession experiences are quite similar to what was presented earlier in relation to employee reaction to mergers and acquisitions (Farndale, Van Ruiten, Kelliher, \& Hope-Hailey, 2011; Seo \& Hill, 2005).

\section{References}

Beck, A. T. (1985). A cognitive model of anxiety formation and anxiety resolution. Issues in Mental Health Nursing, 7, $349-365$.

Beck, K., \& Wilson, C. (2001). Have we studied, should we study, and can we study the development of commitment? Methodological issues and the developmental study of work-related commitment. Human Resource Management Review, 11, 257-278.

Bergman, M. E. (2006). The relationship between affective and normative commitment: Review and research agenda. Journal of Organizational Behavior, 27, 645-663.

Bergman, M. E., Benzer, J. K., Kabins, A. H., Bhupatkar, A., \& Panina, D. (2013). An event-based perspective on the development of commitment. Human Resource Management Review, 23, 148-160.

Chrisman, J. J., Chua, J. H., \& Sharma, P. (1998). Important attributes of successors in family businesses: An exploratory study. Family Business Review, 11, 19-34.

Corbetta, G., \& Salvato, C. (2004). Self-serving or self-actualizing? Models of man and agency costs in different types of family firms: A commentary on "comparing the agency costs of family and non-family firms: Conceptual issues and exploratory evidence”. Entrepreneurship Theory and Practice, 28, 355-362.

Costigan, R. D., Ilter, S. E., \& Berman, J. J. (1998). A multi-dimensional study of trust in organisations. Journal of Managerial Issues, 10, 303-317.

Damasio, A., Everitt, B. J., \& Bishop, F. (1996). The somantic marker hypothesis and the possible functions of the prefrontal cortex. Philosophical Transactions: Biological Sciences, 351, 1413-1420.

Davis, J. H., Allen, M. R., \& Hayes, H. D. (2010). Is blood thicker than water? A study of stewardship perceptions in family business. Entrepreneurship Theory and Practice, 34, 1093-1116.

Davis, P. S., \& Harveston, P. D. (1998). The influence of family on the family business succession process: A multi-generational perspective. Entrepreneurship Theory and Practice, 22, 31-53.

Dawson, A., Sharma, P., Irving, P. G., Marcus, J., \& Chirico, F. (2015). Predictors of later generation family members' commitment to family enterprises. Entrepreneurship Theory and Practice, 39, 545-569.

De Massis, A., Chua, J. H., \& Chrisman, J. J. (2008). Factors preventing intra-family succession. Family Business Review, 21, $183-199$.

Deci, E. L., Connell, J. P., \& Ryan, R. M. (1989). Self-determination in a work organization. Journal of Applied Psychology, 74, 580-590. 
Driscoll, J. W. (1978). Trust and participation in organizational decision making as predictor of satisfaction. Academy of Management Journal, 21, 44-56.

Easton, G. (2010). Critical realism in case study research. Industrial Marketing Management, 39, 118-128.

Eddleston, K. A., Chrisman, J. J., Steier, L. P., \& Chua, J. H. (2010). Governance and trust in family firms: An introduction. Entrepreneurship Theory and Practice, 34, 1043-1056.

Eddleston, K. A., Kellermanns, F. W., \& Sarathy, R. (2008). Resource configuration in family firms: Linking resources, strategic planning and technological opportunities to performance. Journal of Management Studies, 45, 26-50.

Eisenhardt, K. M. (1989). Building theories from case study research. Academy of Management Review, 14, 532-550.

Eisenhardt, K. M., \& Graebner, M. E. (2007). Theory building from cases: Opportunities and challenges. Academy of Management Journal, 50, 25-32.

Elrod, P. D., \& Tippett, D. D. (2002). The “death valley” of change. Journal of Organizational Change Management, 15, 273-291.

Farndale, E., Van Ruiten, J., Kelliher, C., \& Hope-Hailey, V. (2011). The influence of perceived employee voice on organizational commitment: An exchange perspective. Human Resource Management, 50, 113-129.

Fedor, D. B., Caldwell, S., \& Herold, D. M. (2006). The effects of organizational changes on employee commitment: A multilevel investigation. Personnel Psychology, 59, 1-29.

Ford, J. K., Weissbein, D. A., \& Plamondon, K. E. (2003). Distinguishing organizational from strategy commitment: Linking officers' commitment to community policing to job behaviors and satisfaction. Justice Quarterly, 20, 159-185.

Freeman, S. F. (1999). Identity maintenance and adaptation: A multilevel analysis of response to loss. Research in Organizational Behaviour, 21, 247-294.

Friedman, S. D., \& Saul, K. (1991). A leader's wake: Organization member reactions to CEO succession. Journal of Management, 17, 619-642.

Friedman, S. D., \& Singh, H. (1989). CEO succession and stockholder reaction: The influence of organizational context and event content. Academy of Management Journal, 32, 718-744.

Frijda, N. H. (1986). The emotions. Cambridge, UK: Cambridge University Press.

Gagne, M., Koestner, R., \& Zuckerman, M. (2000). Facilitating acceptance of organizational change: The importance of self-determination. Journal of Applied Social Psychology, 30, 1843-1852.

Greiner, L. E. (1998). Evolution and revolution as organizations grow. Harvard Business Review, 76, 55-67.

Guest, D. (1987). Human resource management and industrial relations. Journal of Management Studies, 24, 503-521.

Håkonsson, D. D., Obel, B., \& Burton, R. M. (2008). Rational emotionality: Integrating emotions into psychological climate. In R. M. Burton, B. Eriksen, D. D. Håkonsson, T. Knudsen, and C. C. Snow (Eds.), The designing organizations: 21st century approaches (pp. 59-81). New York, NY: Springer.

Handler, W. C. (1994). Succession in family business: A review of the research. Family Business Review, 7, $133-157$.

Hayek, F. A. (1952). The sensory order: An inquiry into the foundation of theoretical psychology. Chicago: The University of Chicago.

Hayes, S. C., Strosahl, K. D., \& Wilson, K. G. (1999). Acceptance and commitment therapy. New York, NY: Guildford Press.

Herscovitch, L., \& Meyer, J. P. (2002). Commitment to organizational change: Extension of a three-component model. Journal of Applied Psychology, 87, 474-487.

Ip, B., \& Jacobs, G. (2006). Business succession planning: A review of the evidence. Journal of Small Business and Enterprise Development, 13, 326-350.

Iverson, R. D. (1996). Employee acceptance of organizational change: The role of organizational commitment. The Journal of Human Resource Management, 7, 122-149.

Jimmieson, N. L., Terry, D. J., \& Callan, V. J. (2004). A longitudinal study of employee adaptation to organizational change: The role of change-related information and change-related self-efficacy. Journal of Occupational Health Psychology, 9, 11-27.

Johannisson, B., \& Huse, M. (2000). Recruiting outside board members in the small family business: An ideological challenge. Entrepreneurship and Regional Development, 12, 353-378.

Kavanagh, M. H., \& Ashkanasy, N. M. (2006). The impact of leadership and change management strategy on organizational culture and individual acceptance of change during a merger. British Journal of Management, 17, 81-103.

Kets de Vries, M. F. R. (1996). Family business: Human dilemmas in the family firm. London, UK: International Thomson Business Press. 
Koiranen, M. (2003). Understanding the contesting ideologies of family business: Challenge for leadership and professional services. Family Business Review, 16, 241-250.

Kotter, J. P. (1996). Leading change. Boston, MA: Harvard Business School Press.

Kübler-Ross, E. (1969). On death and dying. New York, NY: Macmillan.

Latta, G. F. (2009). A process model of organizational change in cultural context (OC3 model): The impact of organizational culture on leading change. Journal of Leadership \& Organizational Studies, 16, 19-37.

Lazarus, R. S., \& Folkman, S. (1984). Stress, appraisal, and coping. New York, NY: Springer.

Lines, R., \& Selart, M. (2013). Participation and organizational commitment during change: From Utopist to realist perspectives. In H. S. Leonard, R. Lewis, A. M. Freedman, and J. Passmore (Eds.), The Wiley-Blackwell handbook of the psychology of leadership, change, and organizational development (pp. 289-312). West Sussex, UK: John Wiley \& Sons.

Mabey, C., Salaman, G., \& Storey, J. (2000). Strategic human resource management. London, UK: Sage.

Meyer, J. P., \& Allen, N. J. (1991). A three-component conceptualization of organizational commitment. Human Resource Management Review, 1, 61-89.

Miles, M. B., \& Huberman, M. (1994). Qualitative data analysis: A sourcebook of new methods (2nd ed.). Beverly Hills, CA: Sage Publications.

Miller, D., \& LeBreton-Miller, I. (2006). Family governance and firm performance: Agency, stewardship, and capabilities. Family Business Review, 19, 73-87.

Miller, D., Steier, L. P., \& Le Breton-Miller, I. (2003). Lost in time: Intergenerational succession, change and in family business. Journal of Business Venturing, 18, 513-531.

Milliken, F. J., Dutton, J. E., \& Beyer, J. M. (1990). Understanding organizational adaptation to change: The case of work-family issues. Human Resource Planning, 13, 91-107.

Mirvis, P. H. (1985). Negotiations after the sale: The roots and ramifications of conflict in an acquisition. Journal of Occupational Behaviour, 6, 115-136.

Mowday, R. T., Porter, L. W., \& Steers, R. M. (1982). Employee-organization linkages: The psychology of commitment, absenteeism, and turnover. New York, NY: Academic Press.

Nahapiet, J., \& Ghoshal, S. (1998). Social capital, intellectual capital, and the organizational advantage. Academy of Management Review, 23, 242-266.

Nikopolou, M., \& Steemers, K. (2003). Thermal comfort and psychological adaptation as a guide for designing urban spaces. Energy and Building, 35, 95-101.

Nordqvist, M., Hall, A., \& Melin, L. (2009). Qualitative research on family business: The relevance and usefulness of the interpretive approach. Journal of Management and Organization, 15, 294-308.

Parry, W., Kirsch, C., Carey, P., \& Shaw, D. (2014). Empirical development of a model of performance drivers in organizational change projects. Journal of Change Management, 14, 99-125.

Perlman, D., \& Takacs, G. J. (1990). The ten stages of change. Nursing Management, 21, 33.

Piaget, J. (1926). The language and thought of a child. London, UK: Routledge \& Kegan Paul.

Piaget, J. (1930). Child's conception of physical causality. Florence, I: Routledge.

Pieper, T. M., Klein, S. B., \& Jaskiewicz, P. (2008). The impact of goal alignment on board existence and top management team composition: Evidence for family-influenced businesses. Journal of Small Business Management, 46, 372-394.

Porter, L. W., Steers, R. M., \& Mowday, R. T. (1974). Organizational commitment, job satisfaction and turnover among psychiatric tehnicians. Journal of Applied Psyhology, 59, 603-609.

Rashford, N. S., \& Coghlan, D. (1989). Phases and levels of organizational change. Journal of Managerial Psychology, 4, 17-21.

Reynolds, L. (1994). Understanding employees' resistance to change. HR Focus, 71, 17.

Rotter, J. B. (1967). A new scale for the measurement of interpersonal trust. Journal of Personality, 35, 651-665.

Santiago, A. L. (2000). Succession experiences in Philippine family businesses. Family Business Review, 13, 15-35.

Savolainen, S., \& Kansikas, J. (2013). Non family employees in small family business succession: The case of psychological ownership. World Review of Entrepreneurship, Management and Sustainable Development, 9, 64-81.

Scott, W. R. (1987). Organizations: Rational, natural, and open systems (2nd ed.). London, UK: Prentice Hall.

Seo, M. G., \& Hill, N. S. (2005). Understanding the human side of merger and acquisition: An integrative framework. The Journal of Applied Behavioral Science, 41, 422-443.

Sharma, P., \& Irving, P. G. (2005). Four bases of family business successor commitment: Antecedents and consequences. Entrepreneurship Theory and Practice, 29, 13-33. 
Sharma, P., \& Rao, S. A. (2000). Successor attributes in Indian and Canadian family firms: A comparative study. Family Business Review, 13, 313-330.

Sharma, P., Chrisman, J. J., \& Chua, J. H. (2003). Predictors of satisfaction with the succession process on family firms. Journal of Business Venturing, 18, 667-687.

Shin, J., Taylor, M. S., \& Seo, M. G. (2012). Resources for change: The relationships of organizational inducements and psychological resilience to employees' attitudes and behaviours toward organizational change. Academy of Management Journal, 55, 727-748.

Siggelkow, N. (2007). Persuasion with case studies. Academy of Management Journal, 50, 20-24.

Silverthorne, C. P. (2005). Organizational psychology in cross-cultural perspective. New York, NY: New York University Press.

Snow, R. E., Corno, L., \& Jackson, D. (1994). Individual differences in conation: Selected constructs and measures. In D. C. Berliner and R. C. Calfee (Eds.), Handbook of educational psychology (pp. 243-310). New York, NY: Simon \& Schuster Macmillan.

Sonfield, M. C., \& Lussier, R. N. (2009). Non-family-members in the family business management team: A multinational investigation. International Entrepreneurship and Management Journal, 5, 395-415.

Stace, D. A., \& Dunphy, D. C. (1991). Beyond traditional paternalistic and developmental approaches to organizational change and human resource strategies. International Journal of Human Resource Management, 2, 263-283.

Stuart, R. (1995). Experiencing organizational change: Triggers, process and outcomes of change journeys. Personnel Review, 24, 3-87.

Waks, L. J. (2007). The concept of fundamental educational change. Educational Theory, 57, 277-295.

Welsch, J. (1993). The impact of family ownership and involvement on the process of management succession. Family Business Review, 6, 31-54.

Wennberg, K., Wiklund, J., Hellerstedt, K., \& Nordqvist, M. (2011). Implications of intra-family and external ownership transfer of family firms: Short-term and long-term performance differences. Strategic Entrepreneurship Journal, 5, 352-372.

Whelan-Berry, K. S., Gordon, J. R., \& Hinings, C. R. (2003). Strengthening organizational change processes: Recommendations and implications from a multi-level analysis. Journal of Applied Behavioral Science, 39, 186-207.

Yin, R. K. (1994). Case study research: Design and methods. Beverly Hills, CA: Sage.

Zell, D. (2003). Organizational change as a process of death, dying and rebirth. The Journal of Applied Behavioral Science, 39, 73-96.

Sundaramurthy, C. (2008). Sustaining trust within family businesses. Family Business Review, 21, 89-102.

Ward, J. L. (1997). Growing the family business: Special challenges and best practices. Family Business Review, $10,323-337$. 